\author{
Graduate Institute of \\ International and Development Studies Working Paper
}

No: $14 / 2013$

\title{
Financial Development and Economic Growth Known Knowns, Known Unknowns, and Unknown Unknowns
}

\author{
Ugo Panizza \\ Graduate Institute of International and Development Studies
}

\begin{abstract}
This paper summarizes the main findings of the literature on the relationship between financial and economic development (the known knowns), points to directions for future research (the known unknowns), and then speculates on the third Rumsfeldian category. The known knowns section organizes the empirical literature on finance and growth into three strands: (i) the traditional literature which established the link between finance and growth; (ii) the new literature which qualified some of the results of the traditional literature; and (iii) the new-new literature which focuses on alternative measures of financial development and on the dark side of finance. The known unknowns section focuses on causality, on the channels through which finance affects growth, and on the dark side of finance. The unknown unknowns section discusses a topic on which we may know less than what we think we know.
\end{abstract}

\section{(c) The Authors.}

All rights reserved. No part of this paper may be reproduced without the permission of the authors. 


\title{
Financial Development and Economic Growth Known Knowns, Known Unknowns, and Unknown Unknowns
}

\author{
Ugo Panizza \\ The Graduate Institute, Geneva* \\ December 2, 2013
}

\begin{abstract}
This paper summarizes the main findings of the literature on the relationship between financial and economic development (the known knowns), points to directions for future research (the known unknowns), and then speculates on the third Rumsfeldian category. The known knowns section organizes the empirical literature on finance and growth into three strands: (i) the traditional literature which established the link between finance and growth; (ii) the new literature which qualified some of the results of the traditional literature; and (iii) the new-new literature which focuses on alternative measures of financial development and on the dark side of finance. The known unknowns section focuses on causality, on the channels through which finance affects growth, and on the dark side of finance. The unknown unknowns section discusses a topic on which we may know less than what we think we know.
\end{abstract}

\footnotetext{
* Paper prepared for the 2013 AFD-BMZ-EUDN annual conference on development (Berlin, December 11, 2013). I would like to thank François Bourguignon and Stephan Klasen for inviting me to write this paper and for helpful comments and Enrico Berkes, Tito Cordella, Eduardo FernándezArias, and Ricardo Hausmann for useful comments. The usual caveats apply. Parts of Section 2 of this paper draw from Panizza (2012) and Arcand, Berkes, and Panizza (2012).
} 
This paper summarizes the main findings of the literature on the relationship between finance and economic development (the known knowns), points to directions for future research (the known unknowns), and then speculates on the third Rumsfeldian category (the unknown unknowns).

The literature on the links between finance and economic development is enormous and recent surveys are abundant. Levine's (2005) classic survey includes nearly 300 references and more recent surveys by Beck $(2011,2013)$ and Pasali $(2013)$ cover more than 100 papers written after $2005 .^{1}$

As a comprehensive survey would end up being long and repetitive, the known knowns section of this paper concentrates on a selected group of papers and proposes a new way to organize the findings of the literature on finance and growth. Specifically, the section focuses on empirical studies of the links between the size of the financial sector and economic growth. In discussing size, it concentrates on bank credit. ${ }^{2}$

The discussion is organized in three parts. The first part describes the traditional literature that has found a positive link between financial depth and economic growth. The second part, which I label the "new literature on finance and growth," discusses a series of papers that qualify the traditional result of a positive effect of finance on growth. The third part, which I call the "new-new literature on finance and growth," discusses recent papers that move away from traditional measures of size and financial intermediation, and focus on financial innovation and non-intermediation services.

The known unknowns section of the paper focuses on causality, on the channels through which finance affects growth, and on the dark side of finance. This section

\footnotetext{
${ }^{1}$ Over the period 2005-2013, Thorsten Beck, who today is sharing the podium with me, has written nearly 80 papers on the links between finance and economic outcomes (http://ideas.repec.org/f/pbe266.html, accessed on 24/09/2013).

${ }^{2}$ Therefore, the section does not discuss issues related to inequality, poverty-reduction, gender, employment, and financial crises. Moreover, the section does not attempt to summarize the vast literature on bank concentration, on the development of bond and equity markets, on insurance, on the political economy of finance, and on the costs and benefits of bank-based versus market-based financial systems. Finally, my brief summary does not delve into the details of the econometrics of finance and growth. Beck (2011) is a good starting point for readers interested in the literature which is not discussed in this paper. Demirgüç-Kunt and Detragiache (2005) is a good, albeit a bit outdated, summary of the literature on the link between financial development and financial crises. Beck (2009) is a comprehensive survey of the econometrics of finance and growth.
} 
recognizes that there is a limit to what we can do with aggregate data and calls for more research based on firm-level and household-level data.

What about unknown unknowns? These are hard to describe because unknowns are, by definition, unknown. I will thus focus on something about which we think that we know more than what we actually know: an almost unknown unknown. ${ }^{3}$ Specifically, I will question the profession's semi-consensus that state-owned banks have a negative effect on financial and economic development (World Bank, 2001, La Porta et al., 2002).

As the unknown unknowns section aims at stimulating discussion, it is intentionally provocative. However, the reason for writing this section is not provocation but the belief that we need to understand more about the role of the state in the economy. Over the last few years there has been a resurgence of interest for industrial policy in both advanced and emerging economies (Aghion et al., 2012, Harrison and Rodríguez-Clare, 2010). This revival of interventionist policies has been accompanied by a renewed interest and, in some cases, an expansion of the activities of state-owned banks in both developing and advanced economies (IDB, 2013, OECD, 2013).

More research on the role of state-owned banks is needed for at least two reasons. First, evaluating the desirability of an expanded role of these institutions requires establishing whether the negative correlation between state-ownership of banks and financial development identified by La Porta et al. (2002) also implies a causal link. Second, even if state-owned banks do have a negative causal effect on financial and economic development, policymakers may still decide to expand the role of these institutions. ${ }^{4}$ In such a case, knowing more about the channels through which state-owned banks affect economic and financial development would allow us to provide advice aimed at minimizing the risks of this policy choice. ${ }^{5}$

\section{$2 \quad$ Known Knowns}

Levine (2005) describes four main mechanisms through which finance can promote economic development: (i) The pooling of savings through risk diversification and risk

\footnotetext{
${ }^{3}$ Mark Twain is believed to have said: "It's not what you don't know that kills you, it's what you know for sure that ain't true."

${ }^{4}$ They may decide not to listen to their economic advisors or simply pick bad advisors

${ }^{5}$ Assuming that policymakers are ready to listen.
} 
management; (ii) The facilitation of exchange through the reduction of transaction costs; (iii) The improvement of capital allocation through the production of ex ante information about investment opportunities; and (iv) The increase of investors' willingness to finance new projects through ex post monitoring and corporate governance.

With respect to the first mechanism, the focus is on "mobilizing" rather than "generating" savings. While the neoclassical literature on economic growth focuses on savings, Bagehot (1873) pointed out that the main constraint to a country's ability to finance large projects is not the saving rate per se, but the financial system's ability to pool and allocate resources. Profitable investment projects often have two key characteristics: they require a large amount of capital and tend to be risky. Single investors rarely own the capital necessary to finance these projects, and even those who do have the capital might be reluctant to invest a considerable share of their wealth in a single, risky, project (Acemoglu and Zilibotti, 1997). An efficient financial system provides a mechanism that allows big and small investors to diversify risk. Without such a mechanism, individual investors would prefer to allocate their wealth to low-risk, low return projects.

The second mechanism relates to the fact that specialization and division of labor are at the core of modern market economies and such specialization would be impossible without a well-working payment system. Such a payment system is a fundamental public good provided by the financial sector.

The third mechanism has to do with the fact that credit is an information intensive activity. There are substantial fixed costs involved in collecting information about the viability of a given project or the creditworthiness of a given borrower. Financial intermediaries that pool many small investors spread around these fixed costs. This mechanism, together with risk diversification, led Schumpeter to state that the banker is "...the ephor of the exchange economy." (Schumpeter, 1911, p. 74).

The fourth mechanism relates to the ability and incentives of the individuals who supply the capital to monitor their agents (firm managers). A system that provides managers with the right incentives is more likely to mobilize capital towards growth-inducing productive investment. 
A functionally efficient financial system stimulates economic growth through the four mechanisms described above. An inefficient financial system may instead reduce economic growth through misallocation of resources and costly financial crises. ${ }^{6}$

\subsection{The traditional empirical literature}

The empirical literature on finance and growth started in the late 1960s when Goldsmith (1969) used data for 35 countries over the 1860-1963 period to graphically show the presence of a positive correlation between the value of financial intermediaries' assets and economic growth. "Correlation" is the key word here. Goldsmith's findings could not be used to assess whether financial development had a causal effect on economic growth (and he stood clear from drawing such an interpretation for his results). Moreover, Goldsmith did not control for other factors that may be jointly correlated with growth and financial development, and did not test whether the link between financial and economic development goes through productivity or factor accumulation (Levine, 2005).

After a hiatus of nearly 25 years, King and Levine (1993) started filling some gaps in Goldsmith's pioneering work. Using data for 77 countries, and controlling for initial income, school enrollment, government consumption, and trade openness, King and Levine (1993) showed that the size of the financial sector in 1960 predicts economic growth, investment, and productivity growth over the following 30 years.

While King and Levine (1993) experimented with several measures of the size of the financial sector, there is now a consensus that the best indicator of financial depth is credit to the private sector as a share of GDP. The rationale for using this indicator is that financial systems that collect deposits and then channel credit to the government or state owned enterprises may provide a payment system and some services in terms of mobilizing savings but are less likely to exert the other roles of finance (credit allocation, risk management, corporate control) discussed above.

\footnotetext{
${ }^{6}$ The emphasis here is on "functional" efficiency. Tobin (1984) provides four definitions of an efficient financial market: (i) information arbitrage efficiency (prices reflect all available public information); (ii) fundamental valuation efficiency (there are no bubbles); (iii) full insurance efficiency (there is an infinite number of state-contingent Arrow-Debreu contracts); and (iv) functional efficiency. This latter definition relates to the social value added of the financial industry. Since financial markets do not provide services that directly enter in the utility function, the social return of financial intermediation boils down to consumption smoothing, economic growth, and, possibly, lower inequality.
} 
King and Levine's (1993) convincingly showed that financial development predicts growth, but their results did not prove that financial development causes growth. Evidence in this direction can instead be found in successive work by Levine, Loayza, and Beck (2000) and Beck, Levine, and Loayza (2000).

In the first paper, the authors look at a cross-section of 71 countries over the period 1961-95 and use the origin of legal code (La Porta et al., 1998) as an instrument for financial development. They find a strong effect of the exogenous component of financial development on long-run growth and conclude that their results are consistent with the idea that financial development has a causal effect on economic growth.

In the second paper, Beck et al. (2000) use panel data and various Generalized Method of Moments (GMM) estimators (Arellano and Bond, 1991, Arellano and Bover, 1995, and Blundell and Bond, 1998) to look at the determinants of seven five-year growth spells for 77 countries over the period 1960-95. This methodology allows to control for time-invariant country-specific fixed effects and, under certain conditions, to establish causality by using lagged valued of the explanatory variables as instruments. Their results corroborate the cross-sectional findings of Levine et al. (2000) and provide further evidence in support of a causal link going from financial to economic development. Beck et al. (2000) also show that the link between financial depth and economic growth goes through productivity growth and not through factor accumulation.

An influential paper by Rajan and Zingales (1998) addresses the causality issue by looking at the performance of different industrial sectors across countries. Rajan and Zingales start with the observation that industries that for technological reasons need more financial resources should do relatively better in countries with more developed financial sectors. Next, they build an index that captures this industry-level need for financial resources and show that the interaction between this index and financial development is positively correlated with industry-level value added growth, even after controlling for all country and industry-specific factors which may drive the growth rate of a specific industry or country. By checking whether financial development relaxes financing constraints, Rajan and Zingales test a specific mechanism through which finance may affect growth. They can also rule out reverse causality because there is no reason why the deviation between the average growth rate of the manufacturing sector and the growth rate of a given industry should affect financial development in the country as a whole. 
There are also studies that address causality by using natural experiments (such as the branch deregulation that took place in the United States in the late 1970s, Jayaratne and Strahan, 1996) or regional data (such as the effect of local financial development in Italy, Guiso et al., 2004) and find a positive effect of financial development on growth, entrepreneurship, and access to credit by smaller firms.

Although not fully watertight (I will return to the issue of causality in Section 3), the studies described above are consistent with the idea that finance does have a positive causal effect on economic growth. Levine (2005) thus concluded that "the preponderance of evidence suggests that both financial intermediaries and markets matter for growth and that reverse causality alone is not driving this relationship."

\subsubsection{Early naysayers}

When Levine (2005) completed his survey on finance and growth the profession was close to a consensus on the fact that finance does matter for economic growth (with some notable skeptics, among them, Levine mentions Robert Lucas). ${ }^{7}$

There are, however, also some early studies that challenge or qualify the existence of a relationship between financial depth and economic growth. Demetriades and Hussein (1996) use time series techniques and find no evidence of a causal relationship from finance to growth in about half of the 16 countries included in their sample. Arestis and Demetriades (1997) compare the United States and Germany and find that institutional factors may affect the relationship between finance and growth. The importance of institutions is also highlighted by Demetriades and Law (2006) who look at 72 countries for the period 1978-2000 and find that financial development does not affect growth in countries with poor institutions. Similarly, Rousseau and Wachtel (2002) show that the finance has no effect on growth in countries with double digit inflation (their exact threshold is 13 per cent, Yilmazkuday, 2011, also finds that inflation mitigates the correlation between financial development and economic growth).

Some studies find differential effects in developing and advanced economies. De Gregorio and Guidotti (1995) find that in high income countries financial depth is positively

\footnotetext{
7 There were, however, doubts on whether finance matters for convergence or for steady-state growth. Aghion et al. (2005) suggest that financial development accelerates the speed of convergence but has no effect on long-run growth.
} 
correlated with output growth over the 1960-1985 period. When they focus on a panel of 12 Latin American countries, instead, De Gregorio and Guidotti find a negative correlation between financial depth and growth. Deidda and Fattouh (2002) use King and Levine's (1993) cross-country data and a threshold regression model and find that financial development does not have a statistically significant impact on output growth in countries with small financial sectors. Rioja and Valev (2004) use a panel of 72 countries and find that the relationship between finance and growth is particularly strong for countries at intermediate levels of financial development.

Finally, Loayza and Ranciere (2006) recognize that there is a contradiction between the empirical growth literature that studies the effects of financial depth on economic development and the literature that has found that credit growth is one of the best predictor of banking and currency crises (e.g., Kaminsky and Reinhart, 1999). They try to reconcile these two findings by using a panel error correction model to jointly estimate the short and long-run effects of financial development. Their results show that a positive long-run relationship between financial development and economic growth coexists with a negative short-run relationship between these two variables and that this negative short-run relationship is mostly driven by financial crises.

\subsection{The new literature on finance and economic development}

While some of the papers described in the previous subsection showed that the relationship between finance and growth may not hold in countries characterized by poor institutional quality or high macroeconomic volatility, they did not challenge the basic consensus that finance is positively correlated with growth during tranquil periods or in countries with good institutions and macroeconomic policies. However, a series of papers written after the global financial crisis find that the correlation between financial depth and economic growth may fade-away even for countries with good policies and institutions.

Rousseau and Wachtel (2011) show that the positive correlation between finance and growth found in previous studies is not robust to using more recent data. Specifically, they use both cross-sectional and panel data and find that credit to the private sector has no statistically significant impact on GDP growth for regressions that include the post 2000 period (Figure 1). Rousseau and Wachtel (2011) suggest that the vanishing effect may be 
due to a sort of Lucas critique (i.e., financial deepening is associated with growth only if policymakers do not try to exploit this relationship). They test this hypothesis by checking whether the relationship between financial depth and growth disappears during periods of financial liberalization, but do not find any evidence in this direction. They also check whether their result is due to the fact that equity markets have substituted traditional bank financing, but they find that the vanishing effect is not due to the omission of equity markets. Finally, they test for the incidence of financial crises. Their estimations suggest that the vanishing effect may be due to financial crises which are often associated with rapid financial deepening.

Masten et al. (2008) and Arcand et al. (2012) provide an alternative explanation for the vanishing effect. Masten et al. (2008) concentrate on European advanced and transition economies and find a strong growth effect of financial depth in transition economies but no effect in the more advanced EU countries. These authors suggest that while financial deepening may be helpful for transition economies with a relatively small financial sector, the process of financial deepening is no longer necessary for advanced economies in the European Union. The implication seems to be that there are decreasing returns to financial deepening.

Arcand et al. (2012) study whether these decreasing returns can become negative. In other words, they study if there can be "too much finance." They use different types of data (at the country and industry level) and estimators (simple OLS, Panel GMM, semiparametric, differences in differences) to check whether the relationship between financial development and economic growth is non-monotone. They find that the marginal effect of financial development on GDP growth becomes negative when credit to the private sector is close to 100 per cent of GDP (Figure 2, the exact threshold depends on the specification). ${ }^{8}$

Arcand et al. (2012) do not study the channels through which a large financial sector may reduce GDP growth. However, they show that their results are not purely a consequence of poor institutional quality, macroeconomic volatility, or financial instability. The same paper shows that the number of countries with large financial sectors increased rapidly over the last two decades (Figure 3). Arcand et al. (2012) thus suggest that Rousseau and Wachtel's (2011) finding of a vanishing relationship between financial development and

\footnotetext{
${ }^{8}$ Our finding of a non-monotone relationship between finance and growth has been confirmed by successive work by Cecchetti et al. (2012), Pagano (2012), and Dell'Ariccia et al. (2013).
} 
growth could be due to the fact that there are now many countries that have reached the point at which financial deepening starts having a negative effect on growth.

Arcand et al.'s (2012) findings are consistent with the idea that nothing has changed in the fundamental relationship between financial depth and economic growth but that models that do not allow for a non-monotone relationship between financial depth and growth are misspecified. Past empirical work that used data up to the 1990s do not pick up this misspecification because the sample included few countries with a level of financial depth above the point at which finance starts having a negative marginal effect. This idea is supported by the finding that there is no vanishing effect in the quadratic specifications of Arcand et al. (2012).

Another possible explanation for the vanishing effect has to do with the fact that not all credit is the same. While theoretical models tend to study the behavior of enterprises that need external resources to finance investment or working capital, the empirical literature on finance and growth has concentrated on indicators that mix household and firm credit. ${ }^{9}$ Beck et al. (2012) build a new dataset on bank credit composition for a sample of 45 developing and advanced economies over the period 1994 to 2005. They show that there is substantial heterogeneity in credit allocation, with enterprise credit share ranging between 15 and 80 percent of total credit to the private sector. Next, Beck et al. (2012) include their measure of credit composition in a standard growth regression and show that there is a tight correlation between credit to enterprise and economic growth, and no significant correlation between credit to households and economic growth. As there is a positive correlation between total credit to the private sector and the share of household credit (Figure 4), it is possible that the "too much finance" result of Arcand et al. (2012) is really a "too much household finance" result.

\subsection{The new-new literature on finance and economic development}

\footnotetext{
${ }^{9}$ Theoretical predictions with respect to firm credit are unambiguous (except for the fact that there might be some threshold effects, Arcand et al., 2013), but there is no consensus on the growth effect of household credit. On the one hand, Jappelli and Pagano (1994) suggest that household credit may have a negative effect on growth through a reduction of the saving rate. On the other hand, Galor and Zeira (1993) show that credit constrained household underinvest in human capital with a negative effect in overall economic growth.
} 
The empirical literature described in the previous two sub-sections focused on financial depth (i.e., credit to the private sector as a share of GDP). This is a measure of the size of financial intermediation that does not necessarily match the theoretical channels through which finance should affect economic growth (Levine, 2005). The new-new literature on finance and growth explores alternative measures of financial development.

Banks have been moving towards non-intermediation financial activities. An increasing share of the revenues of large and fast-growing banks is now due to fees and other types of non-interest income, and a smaller share of their funding comes from traditional deposit-taking activities (Demirgüç-Kunt and Huizinga, 2010). ${ }^{10}$ The growing importance of these non-intermediation services suggest that the traditional measures of financial depth may no longer be appropriate (if they ever were) to capture the services provided by the financial sector.

Laeven et al. (2013) introduce financial innovation in a traditional Schumpeterian growth model á la Aghion et al. (2005) and show that financial innovation is a key driver of economic growth. Their model predicts that financial innovation (or the rate at which financial systems improve their ability to screen entrepreneurs) affects the speed at which a given country converges to the world economy frontier. ${ }^{11}$ When they take their model to the data, Laeven et al. (2013) proxy financial innovation with the percentage of years between 1960 and 1990 in which a country has had a private credit bureau. According to Laeven et al. (2013), the presence of private credit bureaus is a good match for their model which focuses on the importance of information in determining the allocation of credit. ${ }^{12}$ Their results, based on a cross-section of up to 56 countries for the period 1960-95, confirm that the presence of private credit registries is associated with faster convergence. They also find that, once they control for financial innovation, the level of financial development has no significant effect on steady-state growth or on convergence speed. Laeven et al. (2013) show that only private credit bureaus matter. As public registries collect less information and offer a smaller range of services than their private counterparts, the fact that the

\footnotetext{
${ }^{10}$ These are important, and perhaps dangerous, trends because Demirgüç-Kunt and Huizinga (2010) find that, other things equal, banks that rely largely on non-interest income or non-deposit funding tend to be more risky than traditional banks.

${ }^{11}$ This prediction is different from that of Aghion et al.'s (2005) model which focuses on the relationship between convergence speed and the level of financial depth.

12 The presence of private credit bureaus is closely associated with financial development and credit availability (Jappelli and Pagano, 1993 and Djankov et al., 2007).
} 
presence of public registries does not affect convergence speed is consistent with Laeven et al.'s (2013) view that public credit bureaus are less suitable for the financial innovators at the center of their model. As an alternative proxy for financial innovation, Laeven et al. (2013) use the growth rate of credit to the private sector and find that this variable is significantly associated with convergence speed.

Beck et al. (2012) jointly measure the effect of the intermediation and nonintermediation services provided by the financial sector. Their strategy consists of using the traditional measure of financial intermediation (the log of credit to the private sector) together with a new indicator of the size of the financial system computed as the value added share of the financial system in GDP. The idea is that, by jointly controlling for intermediation and total value added of the financial sector, they can recover the effect of non-intermediation services as the effect of a change in size while keeping intermediation constant. $^{13}$

When intermediation and size are included in separate cross-sectional regressions for the period 1980-2007, both variables are positively correlated with growth. However, when Beck et al. (2012) jointly control for intermediation and size, they find that size is no longer statistically significant (intermediation remains statistically significant in the cross sectional regressions). In panel data regressions neither intermediation nor size is significantly correlated with growth, but intermediation is negatively correlated with volatility (a result which also holds in the cross-sectional regressions) and size is positively correlated with volatility (a result which is consistent with Demirgüç-Kunt and Huizinga, 2010, finding that non-intermediation services increase risk). ${ }^{14}$

When Beck et al. (2012) split their sample between developing and developed economies, they find that neither size nor intermediation is associated with growth in either group of countries (size is statistically significant in one of the three regressions that focus on high income countries), but that size increases volatility in high income countries (intermediation is not statistically significant) and intermediation reduces volatility in

\footnotetext{
${ }^{13}$ If financial intermediaries have monopoly power their value added could capture rents and not the true value of services provided to the economy.

${ }^{14}$ When Beck et al. (2012) estimate their model for the period 1995-2007 they find that neither financial intermediation, nor size are significantly correlated with growth. Instead, the results that intermediation reduces volatility and that size increases volatility still hold.
} 
developing countries (size is not statistically significant). ${ }^{15}$ Beck et al. (2012) conclude that there is no evidence for the financial sector view which maintains that finance can be a growth sector in itself.

A third strand of the new-new empirical literature tries to understand the dark side of finance through the growth impact of the allocation of talents. The possibility that the financial sector may distort the allocation of talents was hinted by Tobin (1984) and has been modeled by Bolton et al. (2011). There is empirical evidence that in many advanced economies the skill content and the relative wage of the financial sector has increased substantially and that these changes (especially skill intensity) are associated with financial deregulation (Philippon and Reshef, 2013, Kneer, 2013). Kneer (2013) shows that high wages in the financial sector may indeed have negative spillovers on non-financial firms. Specifically, she uses KLEMS data for a sample of 13 countries and shows that financial liberalization (especially policies aimed at fostering the development of security markets) tends to attract more skilled workers to the financial sector and that this greater absorption of talents in the financial sector has a negative effect on productivity in industries that for technological reasons rely relatively more on skilled labor.

\section{$3 \quad$ Known Unknowns}

This section reviews the main open questions in the literature on finance and growth.

One issue that has been addressed, but not fully resolved, by the existing literature is causality. As indicated above, while there is strong evidence that financial development is associated with economic growth, some skeptics remain (Rodrik and Subramanian, 2009) and lack of strong evidence of causality is one of the main reasons for this skepticism.

Studies that use country-level data (such as, Levine et al., 2000 and Beck et al., 2000) addressed causality by either instrumenting financial depth with legal origin or by using internal instruments and the GMM estimators developed by Arellano and Bond (1991), Arellano and Bover (1995), and Blundell and Bond (1998).

The first approach relies on the assumption that legal origin has no direct or indirect effect on growth except for the one that goes through financial depth. However, legal origin

\footnotetext{
${ }^{15}$ Regressions that proxy size with EU KLEMS data find a positive effect of size in both growth and volatility.
} 
has been found to be associated with the quality of government (La Porta et al., 1999) which, in turn, is associated with economic development. ${ }^{16}$

The GMM approach, instead, is often deemed to be a black box with results which are highly dependent on the set of instruments included in the equation and the way in which researchers decide to treat the various variables (as fully endogenous, predetermined, or exogenous). The discussion on whether this is a fair criticism to the methodology would be long and technical and does not belong to this paper. However, the profession, which until ten year ago considered this approach the Holy Grail of causality, is now more skeptical of causality claims that only rely on internal instruments.

More work on the determinants of financial development (an area of research that I do not surveyed in this paper but that is discussed in details by Levine, 2005, and Beck, 2011) may be helpful in identifying instruments for a tighter identification of the causal link going from finance to growth.

Studies that rely on industry-level data (such as Rajan and Zingales, 1998) or firmlevel data (such as Demirgüç-Kunt and Maksimovic, 1998) tend to have tighter identification strategies. The problem with these studies is that they can make relative statements or test a specific channel through which finance may affect growth, but they cannot evaluate the full general equilibrium effects of financial deepening.

A second problem with existing research concerns the way in which we measure financial development. Theoretical models suggest that finance stimulates economic growth by facilitating information flows. However, most empirical work does not measure this facilitation role but just some measure of the size of financial intermediation. Levine (2005) and Beck (2011) survey many firm-level studies that use measures of financial development more closely linked to theory, but more work is needed at the cross-country level. The papers by Beck et al. (2011) and Laeven et al. (2013) discussed above are interesting steps in this direction.

We also need more work on the dark side of finance. In discussing what may explain their too much finance result, Arcand et al. (2012) point to several possible channels which determine the threshold at which finance starts having a negative effect on economic growth. A better understanding of these channels is necessary for devising policies aimed at

\footnotetext{
${ }^{16}$ While standard overidentification tests support the validity of these econometric strategy, such tests rely on the assumption that at least one instrument is valid.
} 
pushing the financial sector towards the efficiency frontier and guaranteeing that financial sectors do not trespass the frontier.

The first channel has to do with the fact that the presence of large financial sectors may lead to growth-reducing crises. However, Arcand et al. (2012) show that their results are robust to controlling for financial crises and Loayza and Ranciere (2006) show that crises leads to a negative correlation between finance and growth in the short-run but not in the long run. It is however possible that in the presence of decreasing returns to financial development the marginal cost of maintaining financial stability becomes higher than the marginal return of financial development (de la Torre et al., 2011). In this case, the explanation for the "Too Much Finance" result would not be one of financial crises and volatility (which do not necessarily happen in equilibrium) but one of misallocation of resources.

The second channel focuses on the allocation of talents and suggests that a large financial sector may cause a brain drain from the productive sectors of the economy (Tobin, 1984). Philippon and Reshef (2013) and Kneer (2013) find evidence for such a brain drain and Kneer (2013) shows that the brain drain hurts industries that, for technological reasons, need skilled workers. While the results of Kneer (2013) are intriguing, they are based on an industry-level analysis. Therefore, they do not allow to draw conclusions on the general equilibrium effects of the brain drain.

The third channel focuses on political capture (Johnson, 2009). While there is evidence that politicians are influenced by the lobbying power of the financial industry, I am not aware of any study that examines the growth implications of this channel.

The fourth channel has to do with the fact that financial development (Aghion et al., 2005) or financial innovation (Laeven et al., 2013) only affect convergence and do not have any effect on steady-state growth. I am not aware of any empirical study that looks at the implications of these models for the too much finance result.

Finally, there is the possibility that not all credit is the same (Beck et al., 2012) and that intermediation is no longer at the center of the financial sector (Beck et al., 2013). This is an exciting open area of research that belongs to the new-new literature on finance and growth.

There is a limit to what we can do with aggregate data and more research will need to make use of firm-level and household-level data and then be careful in mapping out 
spillovers and evaluating general equilibrium effects. One interesting area of research concerns how finance can help firm grow. There is evidence that financial development is particularly helpful for smaller firms (Beck et al., 2005, 2008). However, we do not know much about the channels through which finance helps firm growth.

On the one hand, Albuquerque and Hopenhayn (2004) suggest that firm size is endogenous (i.e., firms do not grow because they are not productive) and that small firms with high productivity will naturally experience rapid growth and quickly reach a level of equity at which they no longer face credit constraints. If this is the case, access to finance will speed-up the process but will have limited effect on long-run firm growth.

On the other hand, Jeong and Townsend (2007) develop a theoretical model in which entrepreneurs can choose between traditional and modern production technologies and where modern technologies are especially well-suited for the most talented entrepreneurs. However, modern technologies are costly and talented but poor entrepreneurs without access to credit are forced to use less efficient traditional technologies. Access to credit increases the productivity of talented poor entrepreneurs and, by shifting relative factor prices, discourages rich, but less talented, entrepreneurs to adopt modern technologies for which they may not be well suited. Jeong and Townsend (2007) calibrate their model to the case of Thailand and show that occupational choices and financial deepening can explain about three quarter of total factor productivity growth. It would be interesting to test if such a framework can explain cross-country differences in TFP growth.

Midrigan and Xu (2013) provide a synthesis of the two views by showing that financial frictions can have a large negative effect on productivity because they prevent credit constrained entrepreneurs from entering the modern sector, but that financial frictions have small productivity effects for modern-sector producers.

\section{$4 \quad$ Unknown Unknowns}

It is difficult to discuss unknown unknowns because such unknowns are, by definition, unknown. I will thus talk about a topic on which the economic profession has reached a consensus of sort even though, in my view, we actually know less than what we think we know. In this sense, the relationship between state-ownership of banks and economic development is almost an unknown unknown. 
After two decades of privatization, state-owned banks still control a large share of bank assets in developing economies (Figure 5) and recently there has been a resurgence of interest in these institutions (IDB, 2013 and OECD, 2013). Evaluating the desirability of an expanded role of these institutions requires establishing whether the negative correlation between state-ownership of banks and financial development identified by La Porta et al. (2002) also implies a causal effect. It also requires identifying the channels through which state-owned banks affect economic and financial development.

The main point of this section is that the profession's negative view of state-owned banks does not have a solid empirical justification and that many of the criticisms that have been raised against state-owned banks also apply to the multilateral development banks (such as the World Bank, the Inter-American Development Bank, and the other regional development banks). Therefore, the profession's negative view of national state-owned banks does not appear to be consistent with the profession's more benign view (although, here we are far from consensus) of multilateral state-owned banks. To be clear, I will not claim that state-owned banks have a positive effect on economic development or that the multilateral financial institutions, which I compare to state-owned banks, are useless or harmful for economic development. ${ }^{17}$ I will just point to an inconsistency in the profession's evaluation of these two types of institutions.

\subsection{The consensus and the empirical evidence}

The profession's consensus on the role of state-owned banks is well summarized by the following statement: "state ownership tends to stunt financial sector development, thereby contributing to slower growth" (World Bank, 2001). ${ }^{18}$ My own reading of the empirical literature is not consistent with such a strong statement.

\footnotetext{
${ }^{17}$ In fact, I believe that multilateral development banks are useful institutions and I am aware that there is no evidence either that state-owned banks are good for economic development. In fact, whatever limited evidence we have points in the opposite direction (i.e., towards the consensus view that state-owned banks may harm economic development). However, such limited evidence does not seem to justify the profession's strong views on the role of state-owned banks.

${ }^{18}$ A recent World Bank report (World Bank, 2012) reaches similar albeit more nuanced conclusions. The fact that there is a consensus does not mean that there is unanimity, not even in the top echelons of the profession. There are several well-known economists (e.g., Franklin Allen and Dani Rodrik) who do not share the consensus view described below. See also Adrianova et al. (2012).
} 
At the cross-country level, there is a negative correlation between the presence of state-owned banks and each of financial development and economic growth (La Porta et al., 2002). Such a correlation, however, does not necessarily imply that state-owned banks have a causal effect on financial development or economic growth. To the best of my knowledge there is no paper that convincingly proves that state owned banks have a causal effect on economic or financial development. The negative correlation between the presence of stateowned banks and financial development could be explained by the fact that governments of countries with poorly developed financial sectors have stronger incentives to establish stateowned banks (La Porta et al., 2002, Levy Yeyati et al., 2008). ${ }^{19}$

There is also strong evidence that state-owned banks located in developing countries are less profitable than their private counterparts (Micco et al., 2007). Therefore, state owned banks have a fiscal cost. ${ }^{20}$ However, state-owned banks should not be evaluated on the basis of their financial returns. Their development mandate is likely to reduce profits or entail a loss. If such a loss is necessary for reaching the bank's mandate and the fiscal costs of the state-owned bank is properly recorded in the government's budget, a lossmaking bank could be optimal (De la Torre et al., 2007).

There is also evidence that state-owned banks engage into political lending. They lend more at lower spreads during electoral periods (Dinç, 2005 and Micco et al, 2007) and they target politically connected firms and geographical areas (Khwaja and Mian, 2005, Sapienza, 2005, Carvalho, 2010).

On the positive side, there is evidence that lending by state-owned banks is lessvolatile and less procyclical than lending by private banks (Micco and Panizza, 2006, Bertay et al., 2012). State-owned banks could thus serve as a tool (perhaps not the best tool) for macroeconomic stabilization.

Summing up, the consensus view on the negative effects of state-owned banks rests on three pieces of evidence: (i) the presence of state-owned banks is negatively correlated with each of financial development economic growth; (ii) state-owned banks are less profitable than private banks; (iii) state-owned banks engage in political lending.

\footnotetext{
${ }^{19}$ Such incentives apply to both good and bad governments. Good governments would set up stateowned banks to promote financial deepening. Bad governments would do it to increase their political or economic power.

${ }^{20}$ This could be an explicit fiscal cost if the bank loses money, or just an opportunity cost is the bank has low profitability.
} 
The first two criticisms are problematic because a loss-making state-owned bank could be optimal and there is no evidence that the correlation between the presence of stateowned banks and financial and economic development implies causality. The fact that stateowned banks engage in political lending is an uncontroversial negative aspect of these institutions.

It is, however, unclear whether strong evidence of political lending is enough to justify the consensus view that state-owned banks are bad for economic development. Taking the argument to the limit it would be equivalent to stating that anarchy is preferable to organized government because, instead of being uniquely concerned with social welfare, politicians often engage in activities (sometimes legal and sometimes illegal) aimed at maximizing their own welfare. A proper evaluation of the development impact of stateowned banks would require a careful cost-benefit analysis of these institutions. Among other things, such cost-benefit analysis should recognize that not all state-owned banks are the same. Some state-owned banks are basket cases which just siphon public resources, other (such as KfW and BNDES) are well-managed institutions. Of course, it remains to be seen if these well-managed institutions are worth their cost. This is exactly the question I am asking.

To the best of my knowledge such an evaluation does not exist. This is why I am surprised by the fact that economists, who are normally concerned with rigor, internal consistency, and causality, have been so willing to embrace a consensus view which is not based on strong empirical foundations.

Of course, it could be argued that our prior should be non-intervention and that until we find evidence that state-owned banks are good for economic development the state should stay out of the banking business. This is a reasonable argument. However, this argument is different from my reading of the consensus view on the role of state-owned banks.

\subsection{Two types of state-owned banks two views}


While most economists subscribe to the view that state-owned banks are generally a bad idea, their views on the role of the multilateral development banks tend to be more benign. ${ }^{21}$ I assume that the authors of the World Bank report that concluded that "state ownership tends to stunt financial sector development, thereby contributing to slower growth" did not have the same view about their own employer.

Let us start by considering the criticisms that are normally levied to national stateowned banks and see how they apply to the World Bank. ${ }^{22}$

Does World Bank lending have a positive effect on economic growth in recipient countries? Here opinions vary, but the truth is that we do not know, like we do not know whether national state owned banks have a causal effect on economic growth and financial development.

Is the World Bank more or less profitable than private investment banks? Probably less, but the question does not seem very interesting because the objective function of the World Bank is different from that of, say, Goldman Sachs.

Finally, does the World Bank engage into politically lending? Of course it does! There are some papers that test this hypothesis (e.g., Dreher et al., 2009), but at this point a story is better than one thousand regressions. ${ }^{23}$

In the early 1980s, the IMF asked Erwin Blumenthal (then a senior staff member of the German Bundesbank) to monitor the central bank of Zaire. However, President Mobutu repeatedly blocked Blumenthal attempts to stop the siphoning of funds from the central bank accounts and in 1982 Blumenthal issued a report stating that there was "not any - I repeat any -chance on the horizon that the numerous creditors of Zaire will recoup their funds." ${ }^{24}$ And yet, the money kept flowing in, probably because in 1986 President Reagan stated that:

President Mobutu and I have had the opportunity to review and renew one of our oldest and most solid friendships in Africa, that between the United States and the Republic of Zaire. Cooperation between the

\footnotetext{
${ }^{21}$ Here, however, we are far from consensus, see for instance Melzter (2000), but also Birdsall and Subramanian (2007) who suggest that the World Bank should lend less to sovereigns.

${ }^{22}$ I am choosing the World Bank because it is the largest multilateral development bank.

${ }^{23}$ I learnt this story from Ndikumana and Boyce (2011) and recounted it for the first time in Li and Panizza (2012).

${ }^{24}$ Blumenthal (1982) page 154-5 as quoted in Ndikumana and Boyce (2011), Page 2.
} 
United States and Zaire under President Mobutu's leadership stretches back through 20 years and five U.S. Administrations... Mobutu and his people face a heavy foreign debt burden. We have encouraged Zaire to hold firm to the responsible, economic reforms it is attempting, while promising to do our best to ease the way. ${ }^{25}$

And so they did. Over the period 1980-1990, net flows to Zaire totaled to \$2.7 billion, with $\$ 1.7$ billion of multilateral loans and nearly $\$ 800$ million of bilateral loans (Figure 6). Over the same period, Zaire's total external debt went from 33 per cent to 120 per cent of the country's GDP.

If the presence of political lending is the strongest objection to the existence of state-owned banks, this objection should apply with equal force to the lending activities of the multilateral development banks. ${ }^{26}$

While economists tend to have a negative view about state-owned banks, there is also a sort of consensus on when lending by a state-owned bank is desirable. Such consensus suggests that state-owned banks should target well-identified market gaps and should not crowd out the private sector (Gutierrez et al., 2011). ${ }^{27}$ Do lending activities by multilateral development banks satisfy these conditions? In theory, the answer is yes. In practice, it is less clear.

The theory goes as follows. Sovereign debt is generally not enforceable and nonenforceability leads to widespread credit rationing (see Panizza et al, 2008, for a survey of the literature on sovereign debt). Lending by multilateral development banks relaxes credit constraints and catalyzes private lending because the multilaterals have superior enforcement capacity with respect to private lenders.

This is the theory. What about the practice? At the end of 2011, the International Bank for Reconstruction and Development (IBRD, the non-concessional arm of the World Bank) had outstanding loans with 67 countries totaling approximately $\$ 130$ billion. The three largest borrowers (Mexico, China, and Turkey) accounted for nearly 30 percent of outstanding loans (almost the same share as the 57 smallest IBRD borrowers), the top 5

\footnotetext{
${ }^{25}$ http://findarticles.com/p/articles/mi_m1079/is_v87/ai_4991192/

${ }_{26}$ Interestingly, recent research shows that political motivated disbursements do not, on average, have a large negative effect on the performance of World Bank activities. Large negative effects only arise when the recipient country already faces weak macroeconomic fundamentals (Dreher et al., 2013).

${ }^{27}$ Cohelo et al. (2013) show that public banks do not compete with Brazilian private banks.
} 
borrowers represented 46 percent of IBRD's portfolio, and the ten largest borrowers absorbed more than two thirds of total outstanding loans (Figure 7).

The data do not indicate that the majority of World Bank lending was targeting credit constrained countries. Almost all of IBRD largest borrowers (counting for two thirds of outstanding loans) had full access to the international capital market (Argentina is the exception). ${ }^{28}$ In fact, some of these countries were net lenders on the international capital markets. Consider the case of China which in 2011 had outstanding World Bank loans of approximately $\$ 13$ billion (10 percent of IBRD's portfolio) and was lending approximately \$3 trillion to the governments of several advanced economies (mostly the US).

Why does China borrow $\$ 13$ billion from the World Bank and lends (at a lower interest rate) $\$ 3$ trillion to the government of the advanced economies. ${ }^{29}$ The standard answer is that World Bank loans come with policy advice. ${ }^{30}$ But why does policy advice need to be bundled with a loan? The World Bank could just sell the advice to countries that need it (or give it for free to countries that cannot afford paying for it). What complementarities justify bundling lending with policy advice? One possibility is that the World Bank can give advice because it learnt from previous lending operation. The World Bank learns by lending, this is why it can give policy advice to new borrowers. Can the same reasoning be applied to national development bank? Maybe yes. We are exploring this idea in a paper with Eduardo Fernández-Arias and Ricardo Hausmann.

It is also possible that mixing lending (which generates revenues) with policy advice (which may require a subsidy) is a useful strategy to protect the independence of the institution. A bank that uses its own interest margin to finance its policy mandate will be more politically independent than a state agency that does not generate its own resources (Fernández-Arias et al., 2013). It may be thus argued that the World Bank uses the profits generated from lending to emerging market countries that have access to the international capital market to subsidize IBRD and IDA lending to countries that do not have access and

\footnotetext{
${ }^{28}$ India does not issue sovereign bonds in the international market, but this is probably by choice and not because of the presence of an external credit constraint.

${ }^{29}$ Similarly, why did Mexico, which at the end of 2011 had a total external public debt of \$184 billion, borrow $\$ 13$ billion from the World Bank?

${ }^{30}$ World Bank loans may also buy China (and other large borrowers) political influence within the Bank which, in turn, can be transformed into political influence with the World Bank's smaller borrowers.
} 
may need concessional finance. Again, it is not clear why such a business model would not be appropriate for a national development bank.

\section{$5 \quad$ Conclusions}

This paper consists of three main sections. The first section summarizes the main findings of the literature on the relationship between finance and economic development by organizing this literature into three strands: (i) the traditional literature that has found a positive link between financial depth and economic growth; (ii) the "new literature on finance and growth" which qualifies the traditional result of a positive effect of finance on growth; and (iii) the "new-new literature on finance and growth" which moves away from traditional measures of size and financial intermediation and focuses on financial innovation and non-intermediation services.

The second section of the paper points to directions for future research and focuses on causality, on the channels through which finance affects growth, and on the dark side of finance. This section recognizes that there is a limit to what we can do with aggregate data and calls for more research that uses firm-level and household-level data but that is also able to evaluate the general equilibrium effects of firm-level and household-level estimations.

The third section discusses the role of state-owned banks. It suggests that the profession's consensus that state-owned banks have a negative effect on economic development does not have sound empirical foundations and that we need to learn more about these institutions. The section also argues that most of the criticisms that apply to state-owned banks should also apply to multilateral development banks and asks why the profession has a more benign view for these types of institutions. 


\section{References}

Acemoglu, Daron, and Fabrizio Zilibotti. 1997. "Was Prometheus Unbound by Chance? Risk, Diversification, and Growth,” Journal of Political Economy 105: 709-751.

Andrianova, Svetlana, Panicos Demetriades, and Anja Shortland. 2012. "Government Ownership of Banks, Institutions and Economic Growth," Economica 79: 449-469.

Aghion, Philippe, Mathias \& Dewatripont, Liqun Du, Ann Harrison, Ann, and Patrick Legros. 2011. "Industrial Policy and Competition," CEPR Discussion Papers 8619.

Aghion, Philippe, Peter Howitt, and David Mayer-Foulkes. 2005. "The Effect of Financial Development on Convergence: Theory and Evidence,” Quarterly Journal of Economics 120: 173-222.

Albuquerque Rui and Hugo A. Hopenhayn. 2004. "Optimal Lending Contracts and Firm Dynamics," Review of Economic Studies 285-315.

Arcand, Jean Louis, Enrico Berkes, and Ugo Panizza. 2012 “Too Much Finance?” IMF Working Paper 12/161,

Arellano, Manuel and Stephen Bond. 1991. "Some tests of specification for panel data: Monte Carlo evidence and an application to employment equations," Review of Economic Studies 58: 277-97.

Arellano, Manuel and Olympia Bover. 1995. "Another look at the instrumental variables estimation of error-components models," Journal of Econometrics 68: 29-51.

Arestis, Philip and Panicos Demetriades. 1997. "Financial Development and Economic Growth: Assessing the Evidence," Economic Journal 107: 83-99.

Bagehot, Walter. 1873. Lombard Street: A Description of the Money Market, History of Economic Thought Books, McMaster University Archive for the History of Economic Thought.

Beck, Thorsten. 2009 “The Econometrics of Finance and Growt,.” In Palgrave Handbook of Econometrics, vol. 2, ed. Terence Mills and Kerry Patterson, 1180-1211. Houndsmill: Palgrave Macmillan.

Beck, Thorsten. 2011. "The Role of Finance in Economic Development: Benefits, Risks, and Politics," Discussion Paper 2011-141, Tilburg University, Center for Economic Research.

Beck, Thorsten. 2013. "Finance, Growth and Fragility: The Role of Government," CEPR Discussion Papers 9597, C.E.P.R. Discussion Papers. 
Beck, Thorsten, Hans Degryse and Christiane Kneer. 2013. "Is More Finance Better? Disentangling Intermediation and Size Effects of Financial Systems, “ Journal of Financial Stability.

Beck, Thorsten, Asli Demirgüç-Kunt, Luc Laeven, and Ross Levine. 2008 "Finance, Firm Size, and Growth,” Journal of Money, Banking and Credit 40: 1379-1405.

Beck, Thorsten, Asli Demirgüç-Kunt, and Vojislav Maksimovic. 2005 "Financial and Legal Constraints to Firm Growth: Does Size Matter?” Journal of Finance 60: 137-177.

Beck, Thorsten, Ross Levine, and Norman Loayza. 2000. "Finance and the Sources of Growth,” Journal of Financial Economics, 261-300.

Bertay, Ata, Asli Demirgüc-Kunt, and Harry Huizinga. 2012. "Bank Ownership and Credit over the Business Cycle: Is Lending by State Banks Less Procyclical?" Discussion Paper 2012-049, Tilburg University, Center for Economic Research.

Birdsall, Nancy and Arvind Subramanian. 2007. "From World Bank to World Development Cooperative," CGD Essay, Washington DC.

Blundell, Richard and Stephen Bond. 1998. "Initial conditions and moment restrictions in dynamic panel data models," Journal of Econometrics 87: 115-143.

Bolton, Patrick, Tano Santos and Jose Scheinkman. 2011. "Cream Skimming in Financial Markets,” National Bureau of Economic Research Working Paper 16804.

Carvalho, Daniel. 2010. “The Real Effects of Government-Owned Banks: Evidence from an Emerging Market.” Manuscript, Marshall Business School, University of Southern California, Los Angeles.

Cecchetti, Stephen and Enisse Kharroubi. 2012. "Reassessing the impact of finance on growth," BIS Working Papers 381.

Coelho, Christiano, Joao De Mello, and Leonardo Rezende. 2013. "Do Public Banks Compete with Private Banks? Evidence from Concentrated Local Markets in Brazil," Journal of Money, Credit and Banking 45: 1581-1615.

De Gregorio, Jose and Pablo Guidotti. 1995. "Financial development and economic growth," World Development 2: 433-448.

De la Torre, Augusto, Carlos Gozzi, and Sergio Schmukler. 2007. "Innovative Experiences in Access to Finance: Market Friendly Roles for the Visible Hand?" World Bank Working Paper WPS4326.

Deidda, Luca and Bassam Fattouh. 2002. "Non-linearity between finance and growth," Economics Letters 74: 339-345. 
Demetriades, Panicos and Khaled Hussein. 1996. "Does financial development cause economic growth? Time-series evidence from 16 countries," Journal of Development Economics 51: 387-411.

Demetriades, Panicos and Siong Hook Law. 2006. "Finance, institutions and economic development," International Journal of Finance and Economics 11: 245-260.

Demirgüç-Kunt, Asli and Enrica Detragiache. 2005. "Cross-Country Empirical Studies of Systemic Bank Distress: A Survey," National Institute Economic Review, 192: 68-83.

Demirgüç-Kunt, Asli and Harry Huizinga. 2010. "Bank activity and funding strategies: The impact on risk and returns," Journal of Financial Economics 98: 626-650.

Demirgüç-Kunt, Asli and Vojislav Maksimovic. 1998. "Law, Finance, and Firm Growth," Journal of Finance 53: 2107-2137.

Dinc, Serdar. 2005. "Politicians and Banks: Political Influences on Government-Owned Banks in Emerging Markets," Journal of Financial Economics 77: 453-479.

Djankov, Simeon, Caralee McLiesh, and Andrei Shleifer. 2007. "Private Credit in 129 Countries,” Journal of Financial Economics 84: 299-329.

Dreher, Axel, Stephan Klasen, James Raymond Vreeland, and Eric Werker. 2013. "The Costs of Favoritism: Is Politically Driven Aid Less Effective?" Economic Development and Cultural Change 62: 157-191.

Dreher, Axel, Jan-Egbert Sturm, and James Raymond Vreeland. 2009. "Development aid and international politics: Does membership on the UN Security Council influence World Bank decisions?" Journal of Development Economics 88: 1-18.

Fernández-Arias, Eduardo, Ricardo Hausmann and Ugo Panizza (2013) "Smart Development Banks and Productive Development Policies," unpublished, Inter-American Development Banks

Galor, Oded, and Joseph Zeira. 1993 “Income Distribution and Macroeconomics,” Review of Economic Studies 60: 35-52.

Goldsmith, Raymond W. 1969. Financial Structure and Development. New Haven, Conn.: Yale University Press.

Guiso, Luigi, Paola Sapienza, and Luigi Zingales. 2004."Does Local Financial Development Matter?" The Quarterly Journal of Economics, 119: 929-969.

Gutierrez, Eva, Rudolph, Heinz, Theodore Homa, and Enrique Blanco Beneit. 2011. "Development banks: role and mechanisms to increase their efficiency," Policy Research Working Paper Series 5729, The World Bank. 
Harrison, Ann and Andrés Rodríguez-Clare. 2010. "Trade, Foreign Investment, and Industrial Policy for Developing Countries," Handbook of Development Economics, Elsevier.

IDB. 2013. “Bancos públicos de desarrollo: ¿Hacia un nuevo paradigma?” IDB: Washington DC.

Jappelli, Tullio, and Marco Pagano. 1993. "Information Sharing in Credit Markets,” Journal of Finance 48: 1693-1718.

Jappelli, Tullio, and Marco Pagano. 1994. "Saving, Growth, and Liquidity Constraints," Quarterly Journal of Economics 109, 83-109.

Jeong, Hyeok and Robert Townsend. 2008. "Growth and Inequality: Model Evaluation Based on an Estimation-Calibration Strategy," Macroeconomic Dynamics 12: 231-284.

Johnson, Simon (2009) "The Quiet Coup," The Atlantic, May 2009.

Kaminsky , Graciela and Carmen Reinhart. 1999. "The Twin Crises: The Causes of Banking and Balance-of-Payments Problems," American Economic Review, 89: 473-500.

Khwaja, Asim and Atif Mian. 2005. "Do Lenders Favor Politically Connected Firms? Rent Provision in an Emerging Financial Market," The Quarterly Journal of Economics 120: 1371-1411.

King, Robert G., and Ross Levine. 1993 "Finance and Growth: Schumpeter Might Be Right,” Quarterly Journal of Economics 108: 717-738.

Kneer, Christiane. 2013. "Finance as a Magnet for the Best and Brightest: Implications for the Real Economy," DNB Working Papers 392.

Laeven, Luc, Ross Levine, and Stelios Michalopoulos. 2013. "Financial Innovation and Endogenous Growth," mimeo, UC Berkeley.

La Porta, Rafael, Florencio Lopez-de-Silanes, and Andrei Shleifer. 2002. "Government Ownership of Banks," The Journal of Finance, 57: 265-301.

La Porta, Rafael, Florencio Lopez-de-Silanes, Andrei Shleifer, and Robert Vishny. 1998. "Law and Finance," Journal of Political Economics 106: 1113-1155.

La Porta, Rafael, Florencio Lopez-de-Silanes, Andrei Shleifer, and Robert Vishny. 1999.

"The Quality of Government," Journal of Law, Economics and Organization, 15: 222-79.

Levine, Ross. 2005. "Finance and Growth: Theory and Evidence,” In Handbook of Economic Growth, ed. Philippe Aghion and Steven N. Durlauf, 865-934. Amsterdam: Elsevier. 
Levine, Ross, Norman Loayza, and Thorsten Beck. 2000. "Financial Intermediation and Growth: Causality and Causes,” Journal of Monetary Economics 46: 31-77.

Levy Yeyati, Eduardo, Alejandro Micco, and Ugo Panizza. 2007. "A Reappraisal of StateOwned Banks,"Economía 7: 209-247.

Li, Yuefen and Ugo Panizza. 2013. "The Economic Rationale for the Principles on Promoting Responsible Sovereign Lending and Borrowing," in Carlos Esposito, Yuefen Li and Juan Pablo Bohoslavsky (eds), Sovereign Financing and International Law, Oxford University Press, Oxford.

Loayza, Norman and Romain Rancière. 2006. "Financial Development, Financial Fragility, and Growth,” Journal of Money, Credit and Banking 28: 1051-1076.

Masten, Arjana, Fabrizio Coricelli, and Igor Masten. 2008. "Non-linear growth effects of financial development: Does financial integration matter?" Journal of International Money and Finance 27: 295-313.

Meltzer, Allan 2000. "The report of the International Financial Institution Advisory Commission : comments on the critics ; reform of the international architecture," CESifo Forum 1: 9-17.

Micco, Alejandro and Ugo Panizza, Ugo. 2006. "Bank ownership and lending Behavior," Economics Letters 93: 248-254.

Micco, Alejandro, Ugo Panizza, and Monica Yanez. 2007. "Bank ownership and performance. Does politics matter?" Journal of Banking \& Finance 31: 219-41.

Midrigan Virgiliu and Daniel Yi Xu. 2013. "Finance and Misallocation: Evidence from Plant-level Data," American Economic Review, Forthcoming

Ndikumana, Léonce and James K. Boyce. 2011. Africa's Odious Debts How Foreign Loans and Capital Flight Bled a Continent. ZED Books.

OECD. 2013. "The Role of Public Financial Institutions in Fostering SME's access to finance," Working Party on SMEs and entrepreneurship, unpublished. November 2013 OECD, Paris.

Marco Pagano. 2013. "Finance - Economic Lifeblood or Toxin?" EIEF Working Papers Series 1309, Einaudi Institute for Economics and Finance (EIEF).

Panizza, Ugo, Federico Sturzenegger, and Jeromin Zettelmeyer. 2009. "The Economics and Law of Sovereign Debt and Default," Journal of Economic Literature 47: 651-98.

Panizza, Ugo (2012) "Finance and Economic Development," International Development Policy, 3: 141-160 
Philippon, Tjomas and Ariell Reshef. 2013. "An International Look at the Growth of Modern Finance," Journal of Economic Perspectives, 27: 73-96.

Rajan, Raghuram G., and Luigi Zingales. 1998. "Financial Dependence and Growth,” American Economic Review 88, 559-586.

Rioja, Felix, and Neven Valev. 2004 "Does One Size Fit All? A Reexamination of the Finance and Growth Relationship,” Journal of Development Economics 74: 429-447.

Rodrik, Dani and Arvind Subramanian. 2009. "Why Did Financial Globalization Disappoint," IMF Staff Papers. 56: 112-138.

Rousseau, Peter and Paul Wachtel. 2002. "Inflation thresholds and the finance-growth nexus," Journal of International Money and Finance 21: 777-793.

Rousseau, Peter and Paul Wachtel. 2011. "What is Happening to The Impact of Financial Deepening on Economic Growth?" Economic Inquiry 49: 276-288.

Sapienza, Paola. 2004. "The effects of government ownership on bank lending," Journal of Financial Economics 72: 357-384.

Schumpeter, Joseph. 1911. A Theory of Economic Development, Harvard University Press.

Tobin, James. 1984. "On the efficiency of the financial system," Lloyds Bank Review 153: $1-15$.

World Bank. 2001. Finance for Growth: Policy Choices in a Volatile World. The World Bank, Washington. 
Figure 1a: The effect of financial development on economic growth in different time periods: Cross-country estimations

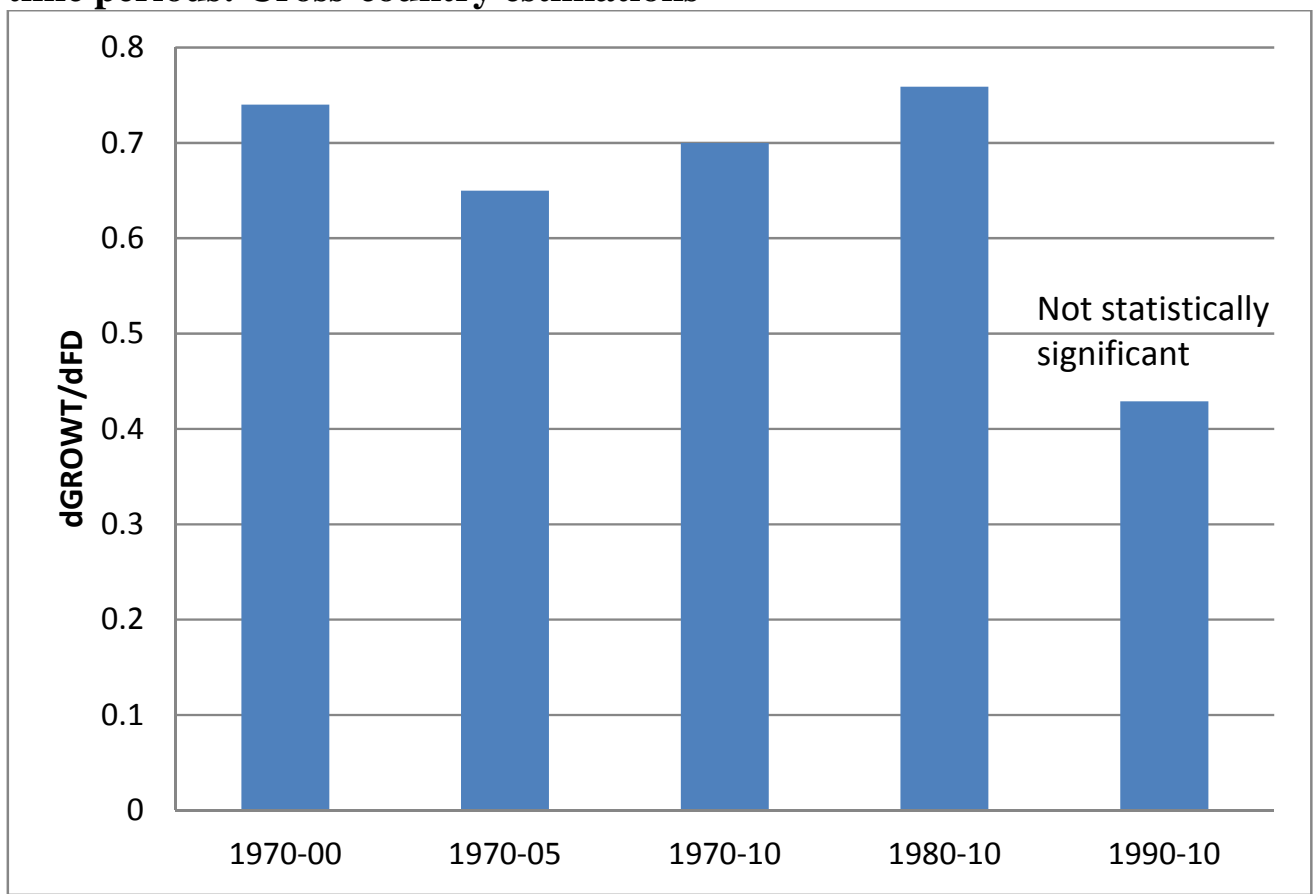

Source: Tables 1 and 2, Arcand et al. (2012)

Figure 1b: The effect of financial development on economic growth in different time periods: Panel estimations

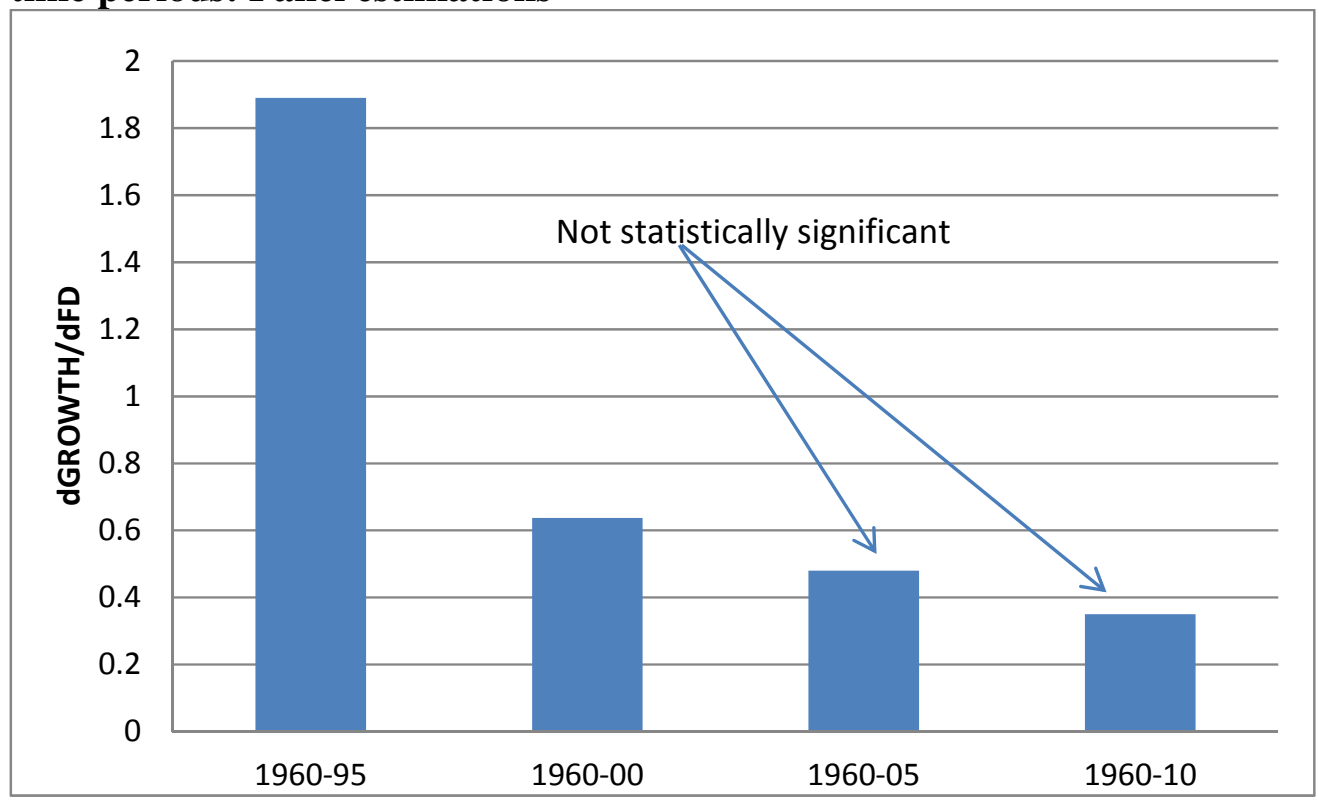

Source: Table 3, Arcand et al. (2012) 
Figure 2: The non-monotonic relationship between financial development and economic growth

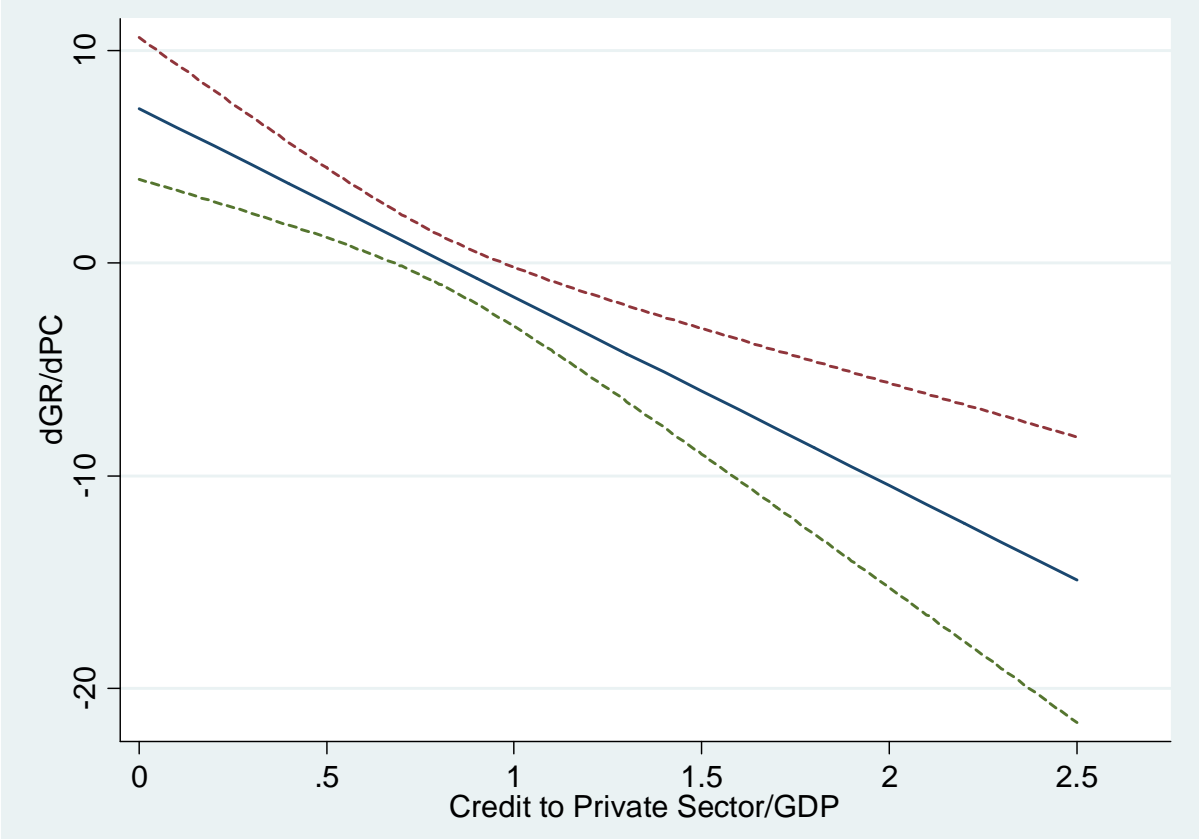

Source: Arcand et al. (2013)

Figure 3: The growth of finance

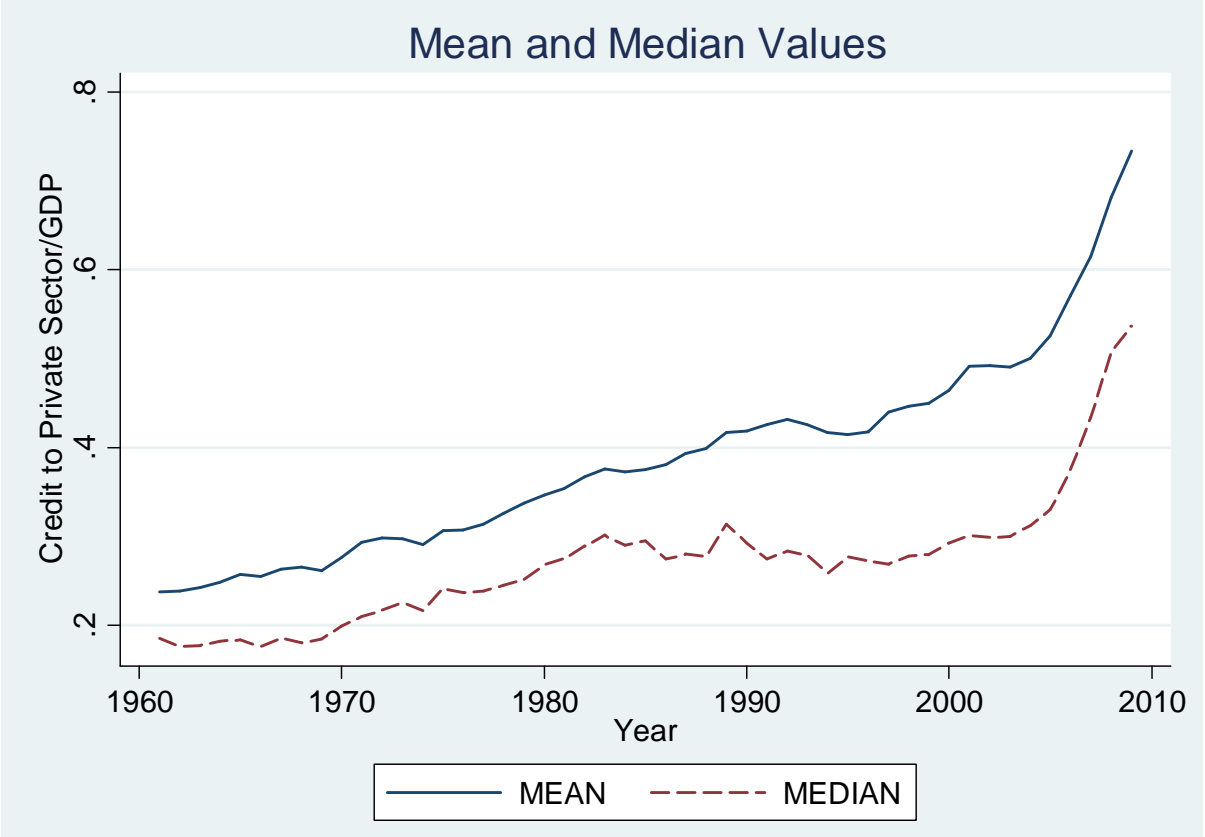

Source: Arcand et al. (2013) 
Figure 4: Financial development and share of household credit

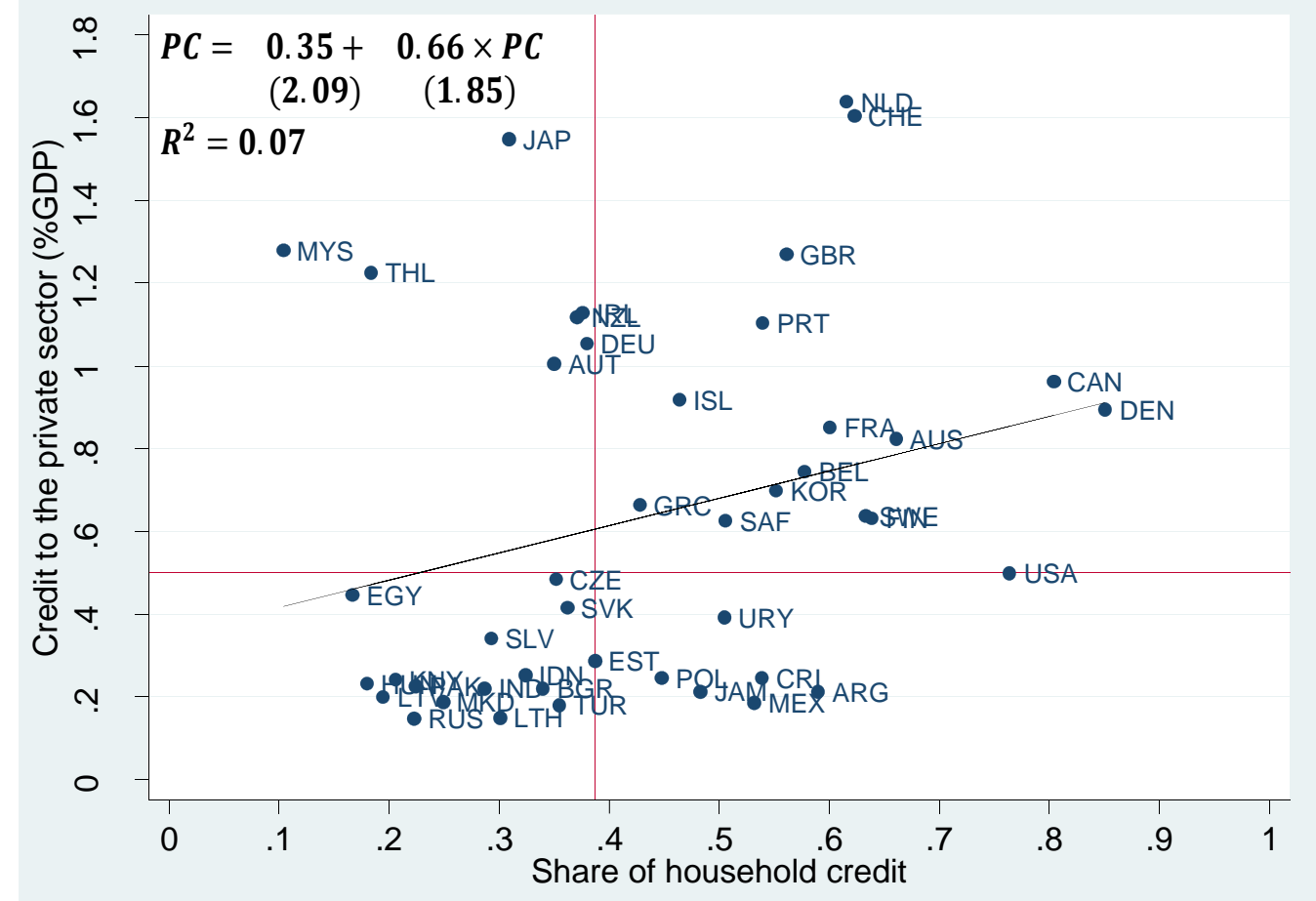

Source: Own elaborations based on data from Beck et al. (2013)

Figure 5: Share of state-owned banks assets over total bank assets

Government Ownership of Banks
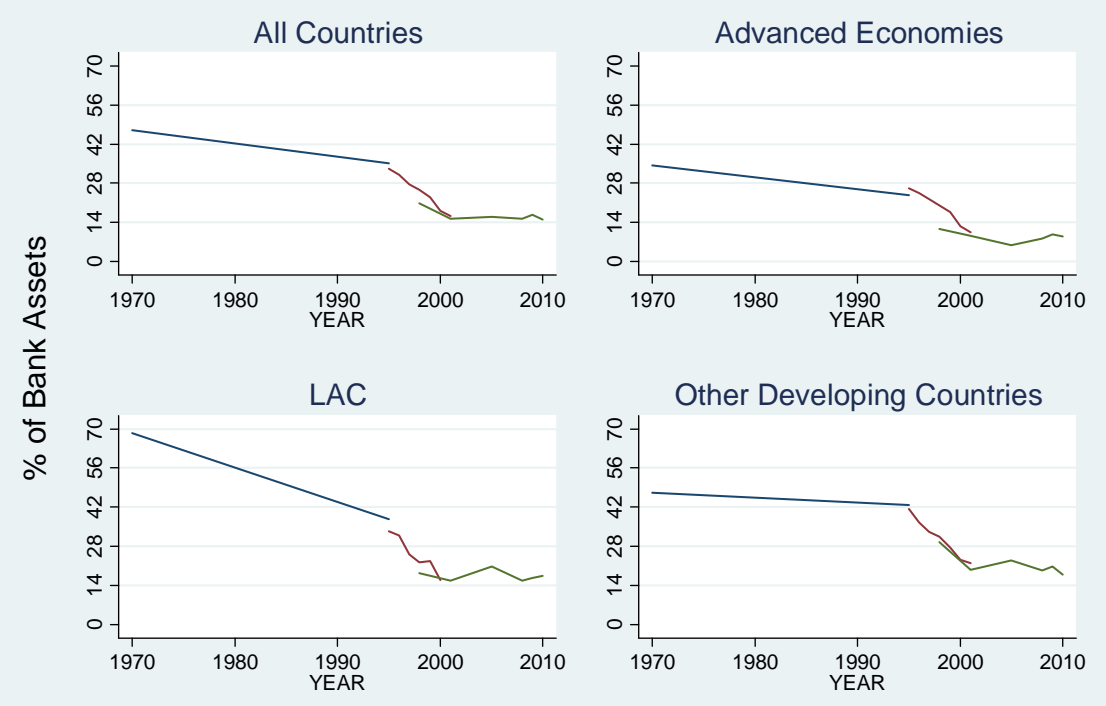
Figure 6: Zaire's external debt

Zaire: Net Financial Flows and External Debt to GDP Ratio

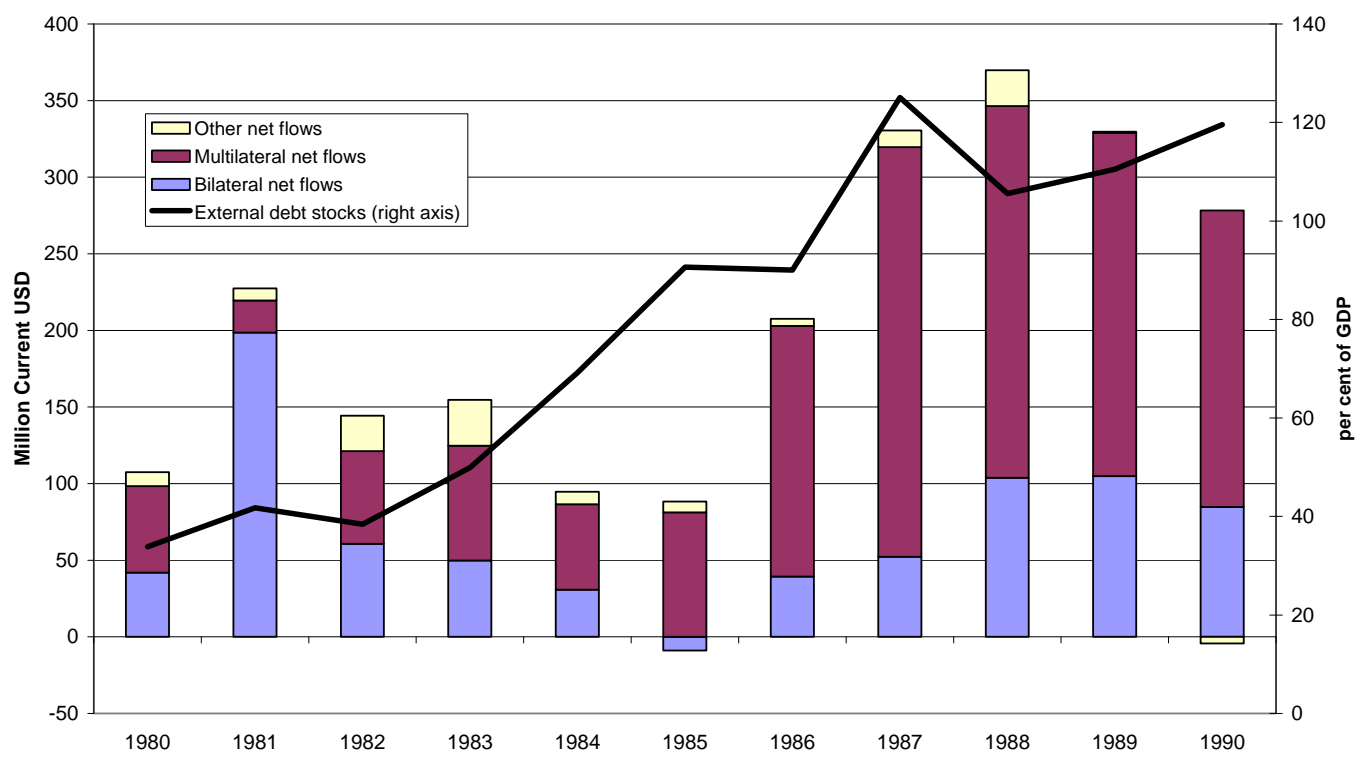

Source: Li and Panizza (2012)

Figure 7: Composition of IBRD outstanding loans (2011)

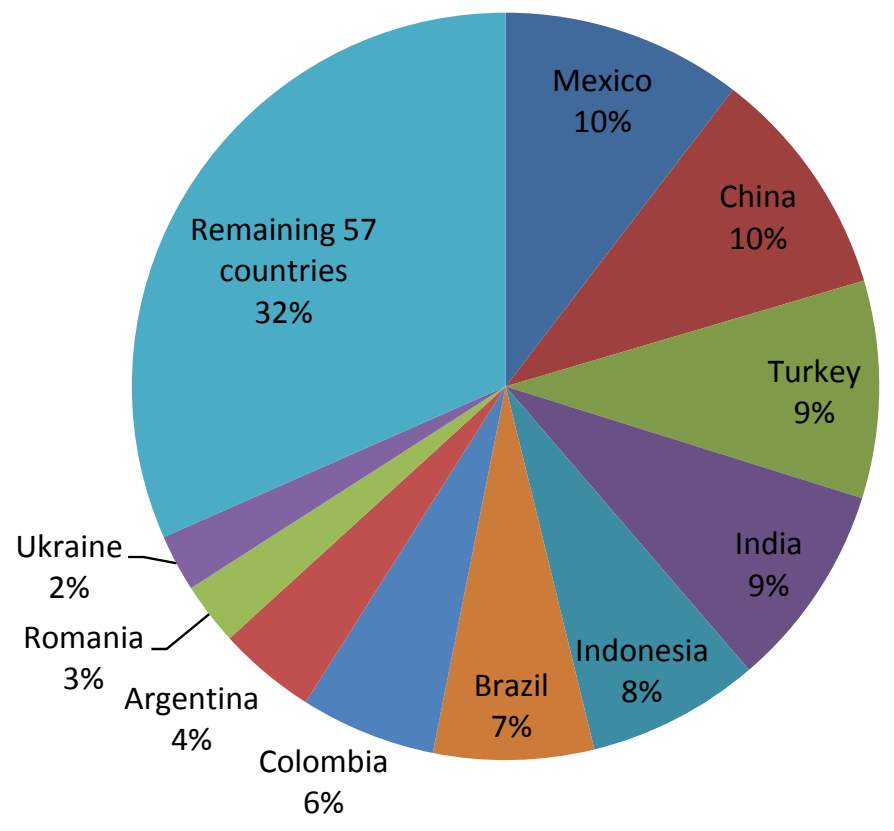

Source: own elaboration based on World Bank data 